\title{
Evaluation of vaginal agenesis treated with the modified McIndoe technique: A retrospective study
}

\author{
Oya Soylu Karapınar ${ }^{1}$, Mustafa Özkan², Ayşe Güler Okyay ${ }^{1}$, Hanifi Şahin ${ }^{3}$, Kenan Serdar Dolapçığlu ${ }^{1}$ \\ ${ }^{1}$ Department of Obstetrics and Gynecology, Mustafa Kemal University School of Medicine, Hatay, Turkey \\ ${ }^{2}$ Department of Plastic and Reconstructive Surgery, Mustafa Kemal University School of Medicine, Hatay, Turkey \\ ${ }^{3}$ Department of Obstetrics and Gynecology, Basskent University School of Medicine, Ankara, Turkey
}

\section{Abstract}

Objective: Retrospective analysis of cases that have undergone neovagina operation because of congenital vaginal agenesis was objected.

Material and Methods: Seven cases applying with the complaints of primary amenorrhea or inability to have sexual intercourse were in the study. The cases were diagnosed with congenital vaginal agenesis and operated at Mustafa Kemal University Training and Research Hospital between 2011 and 2014. Vaginoplasty by the modified McIndoe method was performed in all cases. The main complaint, chromosomal analysis, duration of operation, preoperative and postoperative vaginal length, complications, postoperative treatment, and satisfaction from the sexual intercourse were all evaluated.

Results: Average age of our patients was 28.14 \pm 8.61 (19-39) years. One patient was 46XX-45X0 mosaic Turner syndrome), 1 patient was 46XY (testicular feminization), and other 5 patients were $46 \mathrm{XX}$. The average duration of operation was $2.7 \pm 0.56$ (2-3.5 h). Postoperative infection was observed in 1 patient. In this infected patient, graft failure occurred and debridement was performed in reoperation. No early complications were seen in the others. Preoperative and postoperative average vaginal lengths were $1.85 \pm 0.62(1-3 \mathrm{~cm}) \mathrm{and} 8.71 \pm 1.11(7-10 \mathrm{~cm})$, respectively. Dyspareunia occurred in 2 cases that were not able to use dilatator regularly: 1 because of cancelation of marriage and the other because of postoperative infection; regular sexual life was achieved in remaining 5 (71\%) cases.

Conclusion: Although there is no consensus about the ideal method of making a functioning vagina among different specialties. The modified McIndoe technique is the most applied method by gynecologists and simple, minimally invasive and with low morbidity.

(J Turk Ger Gynecol Assoc 2016; 17: 101-5)

Keywords: Vaginal agenesis, modified McIndoe technique, vaginoplasty

Received: 23 January, 2016 Accepted: 21 April, 2016

\section{Introduction}

Vaginal agenesis is a rare malformation of the Mullerian duct. Since lower vagina is usually normal and middle and upper $2 / 3$ of vagina are absent, it can also be thought as aplasia or dysplasia of the Mullerian duct. Some researchers defended that absence of vagina is not a real syndrome but is a part of symptom complex. When absence of the uterus accompanies with vaginal agenesis, this is called as Mayer-RokitanskyKüster-Hauser Syndrome (MRKH) (1). Also, vaginal agenesis may be encountered as a part of androgen insensitivity syndrome (testicular feminization), Turner syndrome, Morris syndrome, or combined congenital defects (2).

Incidence of vaginal agenesis changes between 1/4000 and $1 / 10000$. Diagnosis is often made at adolescence due to amenorrhea or coital problems $(3,4)$. Abnormalities of sexual organs during this period may cause personality problems and poor body image. Also, inability to get pregnant during adulthood may cause low self-confidence $(5,6)$.

There are several nonsurgical and surgical methods for treat- ment of vaginal agenesis. The purpose of the treatment is to create an adequate passageway for penetration and to facilitate satisfactory sexual intercourse. The McIndoe (AbbeMcIndoe-Reed) technique is the most frequently mentioned procedure in literature (7-9).

In this study, we aimed to present the retrospective results of the modified McIndoe technique that we used in 7 patients who admitted with complaint of primary amenorrhea or inability to have sexual intercourse.

\section{Material and Methods}

The diagnosis of congenital vaginal agenesis was made in 10 cases who were admitted with the complaints of primary amenorrhea and/or inability to have sexual intercourse to Mustafa Kemal University Training and Research Hospital between 2011 and 2014. Vaginal reconstruction was performed to all. Seven cases whom data was reached of were enrolled in the study. The main complaint, chromosomal analysis, duration of operation, preoperative and postop- 
erative vaginal length, complications, postoperative treatment, and satisfaction from the sexual intercourse were all evaluated. Cases were followed up 1-3.5 years postoperatively. All cases underwent clinical examination, pelvic ultrasonography, vaginometry, karyotyping, and MR during preoperative evaluation. Written informed consent was taken from all participants before the operation. Operation was performed in lithotomy position and under general anesthesia. The modified McIndoe technique was applied to all cases. Between bladder and rectum, , transverse incision was made on the blind vagina and a cavity up to peritoneal level (Douglas pouch) was formed by dissecting about 8-10 cm in depth (Figure 1).

At this stage, plastic surgery team was invited to operation. Full thickness skin grafts were obtained bilaterally. Then the skin graft was placed on a mould (Silimed, ERA Medical; Rio de Janeiro, Brazil) and sutured to vaginal apex in such a way that dermal side touches to the mould. Subsequently, the mould (covered with skin graft) was placed and sutured into vaginal cavity (Figure 2).

The patients were administered to the absolute bed rest, and special diet was given for 7 days. After prosthesis was taken out, povidone iodine and saline dressing was applied. Patients were discharged by warning for never removing the moulds (dilatator) given to them during 3 months except the need of toilet and bath in order to prevent contraction of vagina. Patients were allowed to have sexual intercourse only after 3 months. All patients were controlled at every week during the first month and consequently on every month. Patients were informed that they should always replace the mould into the vagina after washing with soap and applying estrogenous cream when they remove it. Afterwards, they were recommended to use the dilatator just at nights for 3 months. Six months after the surgery, if the patient was married, regular sexual intercourse was recommended. If she was unmarried, dilatator use for 1 hour 3 times a week was advised. The data was analyzed using SPSS version 21.0 (SPSS Inc.; Chicago, IL, USA). Continuous variables were expressed as mean \pm standard deviation. Local Ethics Committee approved the study.

\section{Results}

Mean age of our cases was 28.14 \pm 8.61 (19-39) years. One of cases was engaged, and the others were married. Of the cases, 5 were admitted with complaint of primary amenorrhea, 1 was admitted with inability to have sexual intercourse and 1 with desire of child. On examination, external genitalia were normal in appearance in all of the cases and blind vagina was determined in all of them. In 2 cases, uterus and ovaries were not found. Mosaic Turner Syndrome and testicular feminization were diagnosed in them. Of the remaining cases, uterus and ovaries were seen in 3 , and ovaries were seen but uterus in 2 . Magnetic resonance images were normal in all cases except in 1 who was diagnosed as mosaic Turner syndrome. In this case, an ectopic kidney was found in the right pelvis. According to chromosomal analysis, 1 patient was 46XX-45X0 (mosaic Turner Syndrome), 1 patient was 46XY (testicular feminization), and the other 5 patients were 46XX. Patients were operated

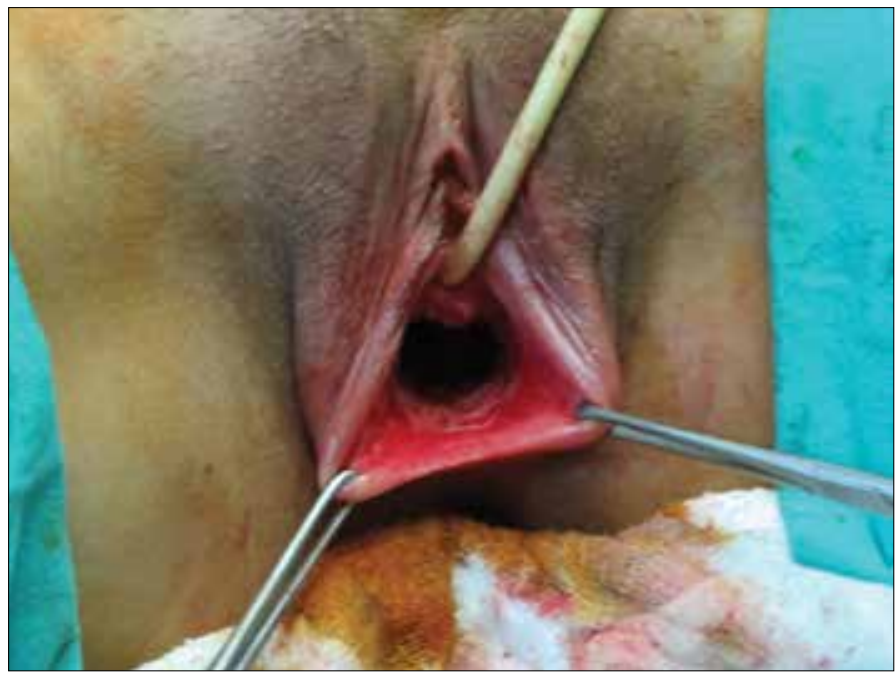

Figure 1. Transverse incision between the rectum and bladder and a cavity up to peritoneal level

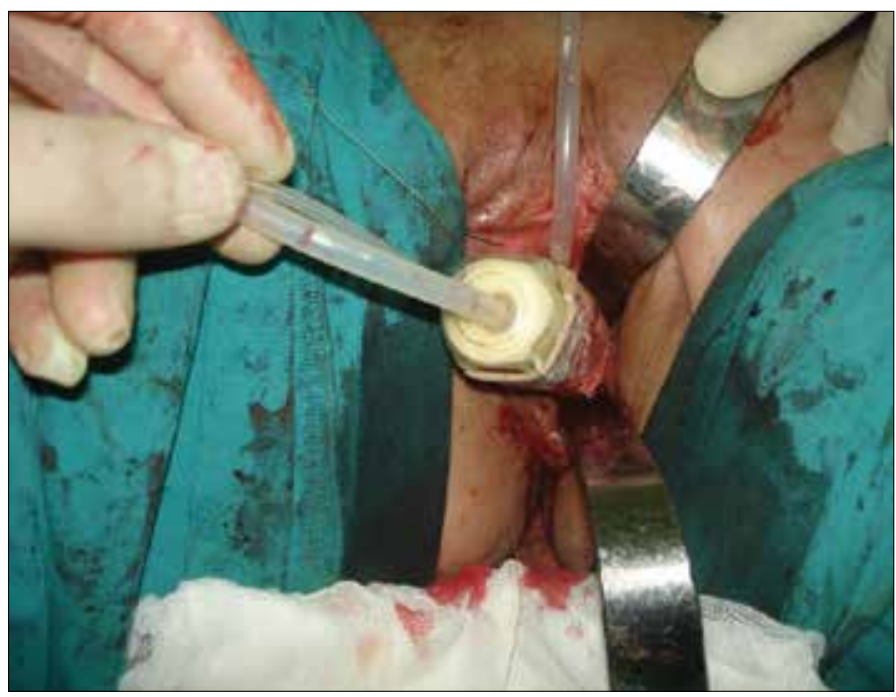

Figure 2. The mould (covered with the skin graft) is being placed into the vagina

by using a full-thickness skin graft by the modified McIndoe technique. Mean time of operation was $2.7 \pm 0.56 \mathrm{~h}(2-3.5 \mathrm{~h})$. Postoperative infection developed in 1 case, and graft failure also occurred in this patient. Therefore, she could not use dilatator. No early complications were seen in other cases, and all of them used dilatator regularly. Preoperative and postoperative findings of cases were summarized in Table 1.

Case 2 who was infected was reoperated and debridement was done. Length of vagina was measured as $6 \mathrm{~cm}$ in later controls. She described rare and painful sexual intercourse and she was advised for continuing to use dilatator. The patients were followed postoperatively for an average of 28 months (10-41 month). Vaginal lengths were $1.85 \pm 0.62(1-3 \mathrm{~cm})$ preoperatively and $8.71 \pm 1.11(7-10 \mathrm{~cm})$ postoperatively. Skin grafts were obtained with success in all patients and pseudomembranous metaplasia developed in all cases except that who was infected. Again except that infected case, regular dilatator use was 
Table 1. Preoperative and postoperative findings of cases

\begin{tabular}{|c|c|c|c|c|c|c|c|}
\hline & Case 1 & Case 2 & Case 3 & Case 4 & Case 5 & Case 6 & Case 7 \\
\hline Age & 36 & 19 & 19 & 39 & 21 & 28 & 35 \\
\hline Complaint & $\begin{array}{c}\text { Primary } \\
\text { amenorrhea } \\
\text { Desire of child }\end{array}$ & $\begin{array}{c}\text { Primary } \\
\text { ameno-rrhea }\end{array}$ & $\begin{array}{c}\text { Primary } \\
\text { ameno-rrhea }\end{array}$ & $\begin{array}{c}\text { Primary } \\
\text { ameno-rrhea }\end{array}$ & $\begin{array}{c}\text { Primary } \\
\text { ameno-rrhea }\end{array}$ & $\begin{array}{c}\text { Primary } \\
\text { ameno-rrhea }\end{array}$ & $\begin{array}{l}\text { Unability to } \\
\text { have sexual } \\
\text { intercourse }\end{array}$ \\
\hline $\begin{array}{l}\text { Chromosomal } \\
\text { analysis }\end{array}$ & $46 X X$ & $46 \mathrm{XX}$ & $46 \mathrm{XX}$ & $46 \mathrm{XX}-45 \mathrm{XO}$ & $46 X X$ & $46 X Y$ & $46 \mathrm{XX}$ \\
\hline Ultrasound & $\begin{array}{l}\text { No uterus, } \\
\text { ovaries were } \\
\text { viewed }\end{array}$ & $\begin{array}{c}2 \text { cm uterus, } \\
\text { ovaries were } \\
\text { viewed }\end{array}$ & $\begin{array}{c}\text { No uterus, } \\
\text { ovaries were } \\
\text { viewed }\end{array}$ & $\begin{array}{c}\text { Uterus and } \\
\text { ovaries were } \\
\text { not viewed }\end{array}$ & $\begin{array}{l}\text { Hematometra } \\
\text { in uterus, } \\
\text { ovaries were } \\
\text { viewed }\end{array}$ & $\begin{array}{c}\text { Uterus and } \\
\text { ovaries were } \\
\text { not viewed }\end{array}$ & $\begin{array}{c}\text { Rudimentary } \\
\text { uterus, ovaries } \\
\text { were viewed }\end{array}$ \\
\hline Preop vaginal length (cm) & 2 & 1 & 1.5 & 3 & 1.5 & 2 & 2 \\
\hline Length of Neovagina $(\mathrm{cm})$ & 8 & 10 & 9 & 7 & 8 & 9 & 10 \\
\hline Complication & None & $\begin{array}{l}\text { Infection, tissue } \\
\text { rejection }\end{array}$ & None & None & None & None & None \\
\hline Dilatator usage & Yes & No, using currently & Yes & Yes & Yes & Yes & Yes \\
\hline $\begin{array}{l}\text { Satisfaction from } \\
\text { sexual intercourse }\end{array}$ & Yes & $\begin{array}{l}\text { Rare, shrinkage, } \\
\text { disparaneua }\end{array}$ & Yes & Yes & Bachelor & Yes & Yes \\
\hline Postop time past (month) & 36 & 13 & 10 & 35 & 37 & 41 & 24 \\
\hline
\end{tabular}

achieved by all patients. One case was engaded and she left the fiance in postoperative period. She was lost at the end of 1-yeartime follow-up and we do not have any information about her current sexual life. The infected case is going on using dilatator and she describes disparaneua. Apart from these 2 cases, remaining 5 cases $(71 \%)$ have satisfactory sexual life currently.

\section{Discussion}

Patients having vaginal agenesis are usually admitted with the complaint of primary amenorrhea at 14-16 years of age. Medications to induce menstruation may have already been given to those cases. Despite in the past making a new vagina have been postponed until just before marriage, , today, performing the operation at 17-20 years of age when patient reaches emotional maturity and intellectual reliability is the accepted approach (1). Surgical and non-surgical methods have been used to correct vaginal agenesis. The aims of treatment are to provide sufficient vaginal depth for penetration and to facilitate satisfactory sexual intercourse. There are surgical methods, such as the Vecchietti techique, Davidoff technique, McIndoe technique (Abbe-McIndoe-Reed), and intestinal vaginoplasty, and nonsurgical methods that are based on continuous dilatation of vagina with a dilatator (7-9).

Despite several available methods to treat vaginal agenesis, the most suitable surgical technique depends on surgeon's experience, advantages and disadvantages of the technique, and also patient preference. Although there is no consensus on the best approach to vaginal agenesis, McIndoe vaginoplasty is the most frequently applied surgical technique (10). Advantages of the original McIndoe technique are feasibility, high success rates, and low morbidity. Possibility of partial or total obliteration is its disadvantage (7-9). We also preferred this technique because of its simplicity, low complication rate, and lack of requirement for abdominal approach.

This procedure consists of creation of a vaginal canal by dissecting the potential neovaginal space that is subsequently covered by a full-thickness skin graft. Several modifications of this technique, especially regarding the material adopted for the canal lining, have been proposed. These include the use of the peritoneum, amnion, allogenic epidermal sheets, Interceed absorbable adhesion barrier, and autologous buccal mucosa $(11,12)$.

Moreover, in vitro autologous vaginal cell cultures obtained from biopsies from the vaginal vestibule were used for the epithelization of the neovaginal walls by Panici for the first time in 2007. Autologous tissue does not carry the risk of infection or allogenic tissue rejection. Since there is no need to "mesh" the material, epithelization is rapid and no visible scars remain. Additionally, this physiological vaginal tissue plays an important role in the achievement of a normal sexual life. Disadvantages include that the procedure can only be performed in centers that have dedicated tissue culture laboratories (12).

The etiology of MRKHS is still poorly understood and is considered as multifactorial disorder. Several studies have investi- 
gated mutations in developmental genes, the analysis of gene expression profiling on cultured cells harvested from vaginal vestibulum biopsy became a feasible approach, focused some genes (13). In this study, we only used chromosomal analysis. In the Vecchietti technique, traction rather than dilatation is needed to create a new vagina. Classical Vecchietti operation was an abdominal surgery that was done abdominally through a Pfannenstiel incision (14); however, this procedure was modified laparoscopically since it has high complication rates (15). This traction process may be too painful, and patients may not tolerate it easily $(14,16,17)$. The Vecchietti technique was used by Fedele et al. (18) and Brucker et al. (19) in 110 and 101 patents, respectively. The achieved vaginal length was well within limits, and nearly $60 \%$ of patients engaged in sexual intercourse without dyspareunia.

Another surgical approach is vaginoplasty by using intestinal grafts. Advantages of this procedure over others are; not requiring mould and dilatation for long time, mucus serving as a natural lubricant, sufficient vaginal length, possibility of early coitus and well long-term results (20). On the other hand, necessity for laparotomy, serious risk of infection, intestinal stenosis, and fistula formation are the disadvantages. Additionally, vagina made from intestinal graft is less sensitive and prone to produce more mucous; patients may have to carry peds continuously (21).

In the study by Bastu et al. (2), no dyspareunia was seen in patients who had vaginal length $8 \mathrm{~cm}$ or more postoperatively. However, success of surgery does not correlate only with postoperative vaginal length. For a successful operation, a functional and sensitive, as well as sufficiently long, vagina should be created. For this reason, adequate metaplasia development in graft is important for elasticity and sensitivity in newly formed vagina. Sexual satisfaction when the McIndoe technique was used has been reported as $80-90 \%$ in the literature $(22,23)$. In our study, considering dyspareunia in 2 patients who were not able to use dilatator regularly, 1 because of cancelation of marriage and the other because of postoperative infection, sexual satisfaction rate was $71 \%$ (5 in 7). Our study is limited because of its' low number of cases; according to our findings, regular dilatator use in patients who does not have a regular sexual relationship is important in order to reach painless and satisfactory sexual intercourse for long period.

Limitations of our study are low number of cases and short duration of post-operative follow-up since some cases were lost to follow-up. Further studies with higher number of subjects and longer period of postoperative follow-up would provide more reliable results about long-term effects of the surgery.

In conclusion; currently there is no consensus on ideal technique among different specialties to create a functional vagina. The McIndoe technique used most frequently by gynecologists has advantages of simplicity, minimal invasiveness, and low morbidity. However, regular usage of the dilatator is the cornerstone of this procedure. Cases should be managed individually, and treatment should be planned and applied by a multidisciplinary team.

Ethics Committee Approval: : Ethics committee approval was received for this study from the Local Ethics Committee.
Informed Consent: Written informed consent was obtained from patients who participated in this study.

Peer-review: Externally peer-reviewed.

Author Contributions: Concept - A.G.O., O.S.K.; Design - O.S.K., A.G.O.; Supervision - A.G.O., K.S.D.; Materials - M.Ö., K.S.D., H.S., Data Collection and/or Processing - O.S.K., H.S.; Analysis and/or Interpretation - O.S.K., A.G.O.; Literature Review - O.S.K., A.G.O.; Writer - O.S.K., A.G.O., K.S.D.; Critical Review - A.G.O., K.S.D.

Conflict of Interest: No conflict of interest was declared by the authors.

Financial Disclosure: The authors declared that this study has received no financial support.

\section{References}

1. Rock, John A. Jones, Howard W. Ovarian cancer: Etiology, Screening and Surgery. Te Linde's Operative Gynecology, 9th Edition. Lippincott Williams \& Wilkins;2003. pp.711-23.

2. Bastu E, Akhan SE, Mutlu MF, Nehir A, Yumru H, Hocaoğlu E, et al. Treatment of vaginal agenesis using a modified McIndoe technique: long- term follow -up of 23 patients and a literature review. Can J Plast Surg 2012; 20: 241-4.

3. ACOG Committee on Adolescent Health Care. ACOG Committee Opinion. Nonsurgical diagnosis and management of vaginal agenesis. Obstet Gynecol 2002; 100: 213-6. [CrossRef]

4. Evans PN, Poland NL, Boving RL. Vaginal malformations. Am J Obstet Gynecol 1981; 141: 910-20.

5. Langer M, Grünberger W, Ringler M. Vaginal agenesis and congenital adrenal hyperplasia. Psychosocial sequelae of diagnosis and neovagina formation. Acta Obstet Gynecol Scand 1990; 69: 343-9. [CrossRef]

6. Freundt I, Toolenaar TA, Huikeshoven FJ, Jeekel H, Drogendijk AC. Long term psychosexual and psychosocial performance of patients with a sigmoid neovagina. Am J Obstet Gynecol 1993; 169: 1210-4. [CrossRef]

7. Giannesi A, Marchiole P, Benchaib M, Chevret-Measson M, Mathevet P, Dragent D. Sexuality after laparoscopic davydov in patients affected by congenital complete vaginal agenesis associated with uterine agenesis or hypoplasia. Hum Reprod 2005; 20 : 2954-7. [CrossRef]

8. Jasonni VM, La Marca A, Naldi S, Matonti G, D'Anna R. The management of vaginal agenesis: report of 104 cases. Fertil Steril 2007; 88: 1653-6. [CrossRef]

9. Lee MH. Non-surgical treatment of vaginal agenesis using a simplified version of Ingram's Method. Yonsei Med J 2006; 47: 892-5. [CrossRef]

10. Panici PB, Bellati F, Boni T, Francescangeli F, Frati L, Marchese C. Vaginoplasty using autologous in vitro cultured vaginal tissue in a patient with Mayer-von-Rokitansky-Küster-Hauser syndrome. Human Reprod 2007; 22: 2025-8. [CrossRef]

11. Panici PB, Ruscito I, Gasparri ML, Maffucci D, Marchese C, Bellati F. Vaginal Reconstruction with the Abbè-McIndoe Technique: From Dermal Grafts to Autologous in Vitro Cultured Vaginal Tissue Transplant. Semin Reprod Med 2011; 29: 45-54. [CrossRef]

12. Nodale C, Ceccarelli S, Giuliano M, Cammarota M, D'Amici S, Vescarelli E, et al. Gene Expression Profile of Patients with Mayer-Rokitansky-Küster-Hauser Syndrome: New Insights into the Potential Role of Developmental Pathways. PLoS One 2014; 9: e91010 [CrossRef]

13. Wesley JR, Coran AG. Intestinal vaginoplasty for congenital absence of the vagina. J Pediatr Surg 1992; 27: 885-9 [CrossRef] 
14. Veronikis DK, McClure GB, Nichols DH. The Vecchietti operation for constructing a neovagina: indications, instrumentation, and techniques. Obstet Gynecol 1997; 90: 301-4. [CrossRef]

15. Fedele L, Bianchi S, Zanconato G, Raffaelli R. Laparoscopic creation of a neovagina in patients with Rokitansky syndrome: analysis of 52 cases. Fertil Steril 2000; 74: 384-9. [CrossRef]

16. Makinoda S, Nishiya M, Sogame M, Mikuni M, Kojo T, Fujino T, et al. Non-grafting method of vaginal construction for patients of vaginal agenesis without functioning uterus (Mayer-Rokitansky-Kuster syndrome). Int J Surgery 1996; 81: 385-9.

17. Fedele L, Bianchi S, Tozzi L, Borruto F, Vignali M. A new laparoscopic procedure for creation of a neovagina in Mayer-RokitanskyKuster-Hauser syndrome. Fertil Steril 1996; 66: 854-7. [CrossRef]

18. Fedele L, Busacca M, Candiani M, Vignali M. Laparoscopic creation of a neovagina in Mayer-Rokitansky-Kuster-Hauser syndrome by modification of Vecchietti's operation. Am J Obstet Gynecol 1994; 171: 268-9. [CrossRef]
19. Brucker SY, Gegusch M, Zubke W, Rall K, Gauwerky JF, Wallwiener D. Neovagina creation in agenesis: development of a new laparoscopic Vecchietti-based procedure and optimized instruments in a prospective comparative interventional study in 101 patients. Fertil Steril 2008; 90: 1940-52. [CrossRef]

20. Ghosh TS, Kwawukume EY. Construction of an artificial vagina with sigmoid colon in vaginal agenesis. Int J Gynaecol Obstet 1994; 45: 41-5. [CrossRef]

21. Freundt I, Toolenaar TA, Huikeshoven FJ, Drogendijk AC, Jeekel H. A modified technique to create a neovagina with an isolated segment of sigmoid colon. Surg Gynecol Obstet 1992; 174: 11-6.

22. Tolhurst DE, van der Helm TW. The treatment of vaginal atresia. Surg Gynecol Obstet 1991; 172: 407-14.

23. Mobus VJ, Kortenhorn K, Kreienberg R, Friedberg V. Long-term results after operative correction of vaginal aplasia. Am J Obstet Gynecol 1996; 175: 617-24. [CrossRef] 